\title{
Industrial development as discursive change: A case of symbiotic learning
}

\author{
Hans Christian Garmann Johnsen
}

\begin{abstract}
The Eyde Cluster is a network of companies at Agder seeking to enhance sustainable development through vocational training. A dialogical approach is taken to developing a new discourse, using principles of communicative organisational change. There is discussion of a more bottom up approach, in line with Workplace Innovation. The paper argues for balancing formal education and vocational training in a way that creates symbiotic learning.
\end{abstract}

Keywords: Cluster, dialogue, discourse, Lean, network, sustainable development, triple bottom line, vocational training, symbiotic learning 


\section{Introduction}

This paper considers the initiative by the Eyde Cluster at Agder to enhance sustainable development through vocational training. The Eyde Cluster, which today has 33 member companies, was established in 2007 as a network of ten companies within process industries at Agder, the southernmost region of Norway. Each of them are world leading in their field. They are intensive in their use of natural resources, and are among the largest multi-national companies in metal and mining.

The companies in the Eyde Cluster have put sustainability high on their agenda. They argue that, in order to survive as companies, they have to develop in a more sustainable way. They also argue that the present speed of use of resources, and the negative environmental consequences of today's production methods, are not sustainable.

In order to set the new direction towards more sustainable development, the network has initiated a training programme that is intended to involve a large group of employees across the ten companies, and at different levels in the organisations. This programme is called Eyde Leader, and the first course in the programme is called Sustainable Process Industry, and was launched in co-operation with the University of Agder in the fall of 2014. The first cohort of participants completed the course in spring 2015, the second in the spring of 2016 and the third cohort started in the fall of 2016.

The motivation behind this training programme is to engage a large group of employees in a discourse on sustainable manufacturing. The objective is not individual skills or training, but to create this discourse. Lars Petter Maltby, former Managing Director of Saint-Gobain Ceramic Materials AS Lillesand \& Eydehavn, Norway, one of the process industry companies that have taken part in Eyde leader, now Managing Director Eyde Innovation Centre, CTO Eyde Cluster, argues that the main purpose of Eyde leader has been to create a network across process industry companies at Agder, thereby sharing knowledge and competence. In addition to that, the Eyde leader programme is expected to create identity across the companies. This paper describes how this course has been developed and perceived by the participants, and discusses the idea of creating industrial change by initiating this kind of discourse.

The course Sustainable Process Industry is an interesting example of a communicative, discursive change process that in form is rather formal, and complies with the formal higher education system, but in content is dialogical and manages to create a new discourse within the business network. The task and purpose of Eyde Leader is in some sense rather abstract (vision towards sustainability, identity formation, competence development, etc.). The paper tries to explain how to handle this ambiguous task and the type of symbiotic learning (Eikeland 2013) that has taken place in the dialogue between researchers and practice.

\section{The case}

Phase one: The Eyde network develops their strategy

At the time when Eyde Leader was developed, the Eyde network consisted of nine process industry companies at Agder, each of them subsidiaries of large, multinational companies. These companies are engaged in mining, metal production, as well as 
chemical production. They consume a considerable amount of energy, and have over the years had a large environment impact. All of them have developed strongly over the last year, not least in terms of reducing pollution parallel to increasing efficiency. About 3,000 employees work in these nine companies at Agder.

The network was established in 2007, and, soon after, it initiated a common visionary project related to Vision 2050 and envisioned a sustainable process industry by 2020 (Landmark, Rodvelt \& Torjesen 2015). As part of this vision, ideas for a leadership training programme were initiated, and a process started to develop what such a training programme should contain.

In the fall of 2013, the Eyde-network contacted the University of Agder, and a project group was established with the intention to develop a leadership programme within the network, called Eyde Leader. The assignment was to develop a structure for training leaders over the coming years towards the new vision. The work was organised in three arenas. Firstly, three project groups within Eyde discussed input to the programme. The three groups had three different assignments; one had background in the Human Resource departments in the companies, one in the Lean forum for the network, and one in the group that had worked with the sustainability vision.

Secondly, two workshops were held, where the three groups and University of Agder participated, with the intention to bring the ideas from the groups together into a consistent whole. The third arena was the meeting place between the Eyde network and University of Agder.

By the spring 2014, a model for Eyde Leader was emerging. The three groups had developed an agenda, with challenges and central topics in each of their areas. Thus the overall challenges for the network were broken down into a set of issues that were regarded as important in the companies. The Human Resource group focused on personal behaviour, communication and leadership. The Lean group formulated Lean inspired ideas on continuous improvement and increased efficiency, while the sustainability group had formulations about increased awareness of global challenges, and a focus on use of resources and pollution.

At this point, the steering group between the University and Eyde had agreed on some overall structural dimensions for the initiative. It was to be an introductory course in sustainable process industry. The course should be given in two versions; one for middle managers and one for people with operational responsibility in production, or team leaders. The first would be a masters level course of 10 ECTS, the second a bachelor level course of 10 ECTS.

The argument for giving the course in the format of the University's adult education system was that it might encourage participants to move forward with other courses within, among others, the Executive MBA at the University of Agder.

Given these two organising processes; the inspiration of the Eyde working groups and the University's formal education structure, two workshops were organised in order to bring the two together. From the working groups came ideas of how to bring the three perspectives together. A model for Eyde leader was proposed, called the Eyde Business System (inspired by the Toyota Business System): 


\section{Eyde Business System}

Problem

solving

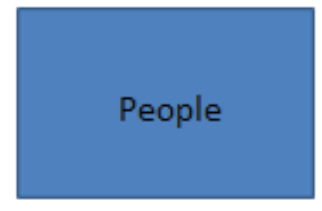

Processes:

technology

Figur 1 Eyde Business System

The philosophy part was described as creating understanding of future challenges. The people part was about leadership, engagement and competence building. The technology part was about utilising technological possibilities and new technologies to reduce waste, increase resource efficiency and reduce pollution. The problemsolving part was the idea that all of this is problem driven. But it also focused on problem solving tools, like Lean and knowledge about work methods.

The concept was cast in business language. The idea was that the philosophy of sustainability should form the foundation from which one would develop new ideas on organisation, use of technologies, care of people and procedures for problem solving. However, looking beyond that, the idea was to combine both operational and long term tasks, and to argue that, at the core of the change process, there was a need to approach future challenges regarding people and technology.

\section{Phase two: The University develops a teaching plan}

In the late spring 2014, the University was given the task of developing these ideas into the two courses. The Eyde network wished to have the courses in parallel, but also to have some teaching separate. The reason for this was the assumption that process-managers that were on the shop floor, and often team leaders of the operating team around a machine or process, would have different issues to discuss among them, and perhaps less experience with the study situation, than the middle managers. On the other hand, one wanted the two groups to communicate. The Eyde network also wished to involve the top managers of the companies involved in the course as speakers. It was decided to do this by having one top manager from one of the companies to give an hour of introductory lecture to each of the five course meetings.

The researchers from the university involved in this process came from management studies and social science. Sustainability is a concept that is easily associated with 
physical things like pollution and climate change. It was made clear from the researchers that their approach to sustainability was more related to the social and organisational aspects of this concept, than to the more technological aspects. Thus sustainability was defined as a form of triple bottom line: social, economic and environmental satiability. The intention of the leadership training was formulated as finding ways to balance these three aspects and intentions.

It was decided to have five course (teaching) sessions, each over two days. The first teaching session for the first cohort was in mid-September 2014, the fifth and last in mid-April, 2015. Each session had an overall theme. The first introduced the concept of sustainable process industry. The second had people and leadership and the Norwegian model as a theme, the third had sustainability and global challenges as the overall theme, the fourth had continuous improvement and Lean as a theme, and lastly the fifth had sustainable work systems as a theme.

For these five teaching sessions, we choose the following literature: An introductory book on Lean (Wig 2013), a book about the Norwegian work life model (Levin, Tove, Ravn \& Øyum 2012), book and articles on sustainability (Heck \& Rogers 2014; Vision 2050; Elkington 2012; Porter \& Kramer 2011; Winston 2014) and a book on sustainable work systems (Docherty, Kira \& Shani 2008). We also used John Kotter's (1996) book "Leading Change", as part of that change management teaching. All of these books were for the Master's course, while only the Norwegian books and articles were used for the Bachelor course. All in all, eight different university professors took part in the teaching over the five teaching sessions, in addition to top managers of five of the companies in the Eyde network, and representatives of the Eyde work groups that had participated in developing the programme.

\section{The running of the courses}

A little more than 30 managers, half at process level (Bachelor) and half at midmanagers level (Master), signed up for the course when it started in mid-September 2014. The first teaching session introduced the idea of the course and the vision for the Eyde network, including Vision 2050.

After this first teaching session, some of the participants reacted to the programme by arguing that they thought this was going to be "ordinary" leadership training, and that they were unprepared to be approached with a lot of sustainability stuff. Staff from the university had a meeting with one company which in particular represented these reactions. During the meeting the history behind the course was presented, and the expectations by the participants were explained.

From this meeting we learned two things: that the idea of the course had not been communicated thoroughly to those who participated, and that neither were they aware of the visions of the Eyde network. The aftermaths of this clarification led to a couple of participants leaving the course, but those who continued were more motivated than before.

The second teaching session had leadership and organisational development as a theme, and was met with much enthusiasm. The rest of the teaching sessions went well, and the courses were finished according to plan. As the course proceeded, more and more teaching was done with both courses in the same room. The last teaching session spent all the time with the two courses together. 
The student's performance

For students to pass the course, they needed to write a group paper. In order also to get grading for the course (so that it would count in the ordinary university system), each student needed to have an oral exam. 25 students completed the two courses. Students were grouped in eight groups (three at Bachelor level, five at Masters level). All groups were organised across companies. The groups picked subjects for their group work, and based on that were assigned a supervisor from the university.

All eight groups made empirical surveys to support their discussion. At Masters level, two were on leadership, one on organisational structure/change one on Lean and one on sustainability. The last one discussed at a strategic level, the others at an organisational level. In the Bachelor class, one paper was on organisational change and efficiency, one on organisational culture and one on learning organisation/Lean. In the last teaching session, the eight groups presented their paper to the rest of the students before their final hand in, and got feedback and discussions related to that. All the papers passed. Only four students, all at Masters level, chose to take the exam. All got an A. In the second cohort, twelve participants assigned for the exam. Grades were slightly more distributed.

\section{Evaluation of the courses}

There was a meeting between the Eyde network and University of Agder before the fifth and final teaching session. There the Eyde network reported on their board meeting, where they had decided to continue the courses with a new cohort to start in September 2015. In the last teaching session there was an evaluation of the whole course. The two courses were combined and the evaluation done as a focus-interview. The students were grouped into four focus groups mixed with both Bachelor and Masters students. They were asked to comment on three themes: the impact of the course, the structure and operation of the course, and the network that was formed.

The evaluation gave some practical input to the managing of the course, including better information to participants, principles for forming the groups, and adjustment of the literature. These inputs were taken into account as the next cohort was being prepared. The most important input from the evaluation was support for the wide scope of the course. One recommended keeping sustainability as a perspective and vision, even if the more practical inputs were more useful. The participants had comments on how their learning was understood in the companies, and argued that the top managers did not share this insight. They saw the network among companies, and the relation they had developed to colleagues, as very useful. They wanted more engagement from the theme groups within the Eyde network.

Based on the papers that were delivered, and the exam, we could add some insight. Firstly, participants say they have got a wider understanding of sustainability; it turned out to be a more comprehensive concept than they had been aware of, as it covers both physical and social issues. Secondly, even though all these companies adhere to Lean, there are many different versions of Lean, and in most companies it is contextualised and mixed with the companies' traditional structure and routines. Thirdly, they acknowledge that a change in direction for the industry is a long term process that will imply commitment and attention over time. Finally, it seems to be generally acknowledged that the theme of efficiency, Lean, sustainable work systems and sustainability, are issues that requires competence in leadership at all 
organisational levels. Finally, and where there is great potential and a need for improvement and change. These insights were used in the planning for the second cohort.

\section{Theory of Industrial development as discursive change}

Based on this case, I would like to reflect on theoretical perspectives on industrial development as discursive change. My starting point in these reflections is the communicative turn in Norwegian wok life research (Gustavsen 1992; Toulmin \& Gustavsen 1996; Pålshaugen 2002). There were two main philosophical roots to this turn; one came from Habermasian theory; the other came from pragmatism (Johnsen 2001).

\section{Communicative change and vocational training}

The concept of communicative organisational change focuses more on legitimacy and the procedural ways by which their changes are made, than the actual content of the changes. Gustavsen (1992 p.70) argues that there might be four groups of results, and that these might be related. The four groups are:

1. change in patterns of communication

2. change in what issues are defined as subject to development and in the way in which the development work is performed

3. change in work organisation

4. change in the selection and configuration of technological elements 
One can try to illustrate the difference between organisational in more conventional forms and organisational through communicative processes as in the table 1.

\begin{tabular}{|l|l|l|}
\hline $\begin{array}{l}\text { Development } \\
\text { al stages }\end{array}$ & $\begin{array}{l}\text { Communicative change with } \\
\text { reflection and participation }\end{array}$ & $\begin{array}{l}\text { Conventional change with } \\
\text { directions and incentives }\end{array}$ \\
\hline Involvement & $\begin{array}{l}\text { Involvement as a result of } \\
\text { willingness to communicate, } \\
\text { trust in the process, reflection, } \\
\text { interpretation and } \\
\text { reconsideration of own } \\
\text { arguments and beliefs }\end{array}$ & $\begin{array}{l}\text { Motivation through incentives } \\
\text { and extrinsic rewards or intrinsic } \\
\text { motivation such as learning, } \\
\text { adoption and personal growth }\end{array}$ \\
\hline Co-ordination & $\begin{array}{l}\text { Co-ordination of interests and } \\
\text { bargaining for voluntary } \\
\text { interaction, establishment and } \\
\text { construction of norms, respect } \\
\text { of procedure, striving at truth, } \\
\text { accepting roles and moral } \\
\text { obligations }\end{array}$ & $\begin{array}{l}\text { Adjustment to organisational } \\
\text { structures through self- } \\
\text { transformation (endogenous } \\
\text { preferences), unintended } \\
\text { consequences of action, framing, } \\
\text { bandwagon effects and games. }\end{array}$ \\
\hline $\begin{array}{l}\text { Institutio- } \\
\text { nalisation }\end{array}$ & $\begin{array}{l}\text { Make validation of rules and } \\
\text { role conformity, legitimacy of } \\
\text { rules maintained by } \\
\text { moral/ethical discourses }\end{array}$ & $\begin{array}{l}\text { Creating internal coherence } \\
\text { through: cultural pressure, team- } \\
\text { pressure, commitment and } \\
\text { conformism }\end{array}$ \\
\hline
\end{tabular}

Table 1 Communicative and conventional theories on individual involvement (Source: Modification form Johnsen (2001))

Gustavsen (1992) argued that the characteristics of dialogue oriented processes are distinct from more conventional approaches to organisational change. The main difference is that the researcher in communicative change process is herself a participant. He argues that:

- $\quad$ The logic of the project: Interactive

- $\quad$ Chief theoretical source: Theory of participative democracy

- $\quad$ Legitimacy: Participation in the process which creates solutions

- $\quad$ Leading actors: Many

- Definition of initial conditions: On-going process

- $\quad$ Situational map: Minimally structured

- $\quad$ Procedure: Stepwise

(Gustavsen 1992 p. 7)

Common to the communicative change concepts are that change grows out of the practical, experiences or situation one is embedded in. Also common to these ideas are that change grows from below, and according to the meaning that participants put 
into the dialogue. It is assumed that by talking and becoming aware of one's own experience as well as others, one is able to develop common perspectives for change.

The advantage of this type of change process is that it is based in the organisation and understood in a common way. The process develops commitment to the common understanding. Top-down changes often have the shortcomings that their intentions are not commonly shared. On the other hand, one can argue that bottom-up changes can become too embedded, too small steps, and not sufficiently visionary or innovative.

There has to be motivation to participate, with rules for participation and a practical intention with participation, in order for this type of change process to give meaning. The challenge with the Eyde-leader programme is that the practical intention is less clear than what is normally the case at workplaces. Furthermore, the programme has not grown out of a strongly felt need for change at the workplace, rather as a wish to make change at a more strategic level. Thus, the programme is only a small step in a process with a not-so concrete goal.

\section{Designed change and organic development}

Comparing the case I have presented with the principles of communicative organisational change, one might ask if the case lives up to the principles of communicative-based change. One could argue that the programme has been designed from a distance, with strategies set out by senior management and the University. Participants, at least in the beginning, seem not to have understood the objectives of the programme or the policies of the network.

The programme has been driven top down, using a pre-determined model. The MBA seems to have a central role. Does this serve to root participants in the past? How does the network operate, to what extent are the workforce engaged? The focus seems to be on senior level management, rather than the wider workforce. The pilot student cohort was small. Can it influence wider company culture? One could think of such a programme in a more bottom up way, focusing on the tacit knowledge of participants and support to develop this further (Ennals, Göranzon, Nelson \& Alvunger 2016). Furthermore, one might ask:

- To what extent can we describe these courses as "outside the conventional educational system"?

- Why did the companies choose to take part in the network and the programme?

- How do member companies work together? How is the network managed and facilitated? Is it a matter of network orchestration?

- What, if anything, has been learned from the experience of regional development coalitions? Has there been initiative fatigue?

- Does the programme address issues of knowledge, including tacit knowledge, or does it rely on conventional academic texts?

- Is the programme part of a wider strategy at the University of Agder, working with company networks across the region? How have University practices changed? Has the University learned?

- How is dialogue conducted within and between companies? 
There are subsequently good and relevant questions to be asked about the way this case has been designed. As I see it, the Eyde network has taken one small step in a direction of creating a dialogue on sustainability. It will take time to develop this further, and involve a substantial amount of the 3000 employees in these companies. That is why the network put up a vision with 2050 as a framework.

In this programme, sustainability was discussed in terms of building mutual competence (Johnsen, Torjesen \& Ennals 2015). Included in this concept is the idea that some sort of common knowledge has to be developed, and that some learning has to include traditional academic learning. The point here is that this change process does not grow out of specific immediate needs in the companies. They are all more or less doing well. The point is rather, that this is a process of developing a new awareness. Even though this development has been initiated from above, the process itself has been open and critical. However, the task has been to initiate abstract organisational learning, it has not been to direct anyone.

\begin{tabular}{|l|l|l|}
\hline & Individual & Organisational \\
\hline Concrete & A) Simple learning & $\begin{array}{l}\text { B) New procedures, } \\
\text { routines and patterns of } \\
\text { cooperation }\end{array}$ \\
\hline Abstract & $\begin{array}{l}\text { C) New beliefs, } \\
\text { change of values }\end{array}$ & $\begin{array}{l}\text { D) Creating a new } \\
\text { paradigm, perspective, } \\
\text { vision for the organisation }\end{array}$ \\
\hline
\end{tabular}

Table 2 Different forms of learning

As illustrated by table 2, the task of stimulating type D) learning is quite different from the process that lead to type A) learning. Thus, one argument for choosing a type of hybrid solution, between a communicative process and a formal education process, is that the university can function as an arena for critical discussion, beyond the interests and power structures of the companies.

The present paper does not address these questions entirely, which are relevant for further investigation into this case. They will require a more longitudinal study than the one presented here. Currently the Eyde Cluster is committed to develop this Eyde leader programme further. They see Eyde leader as an important contributor to building a communicative culture within the Cluster. They also see new, relevant fields appearing, such as circle economy, sharing economy and Industry 4.0, that they want to address. They want a certain number of employees to get experience with the programme in order to create a viable dialogue on sustainability. Thus, there is both a time and a numeric dimension in this type of development processes.

It can be argued that what characterises the current case, is that it has been an attempt to create new forms of learning. One could argue that the topic of sustainability is an abstract, partly metaphorical concept. The course has tried to create a common vocabulary for a dialogue on a sustainable future, and make that issue move from being abstract to become less abstract. I have addressed the role of design in such a discursive development and learning process. The pedagogical model has included lectures, discussions, reflections in groups, so we could argue that the type of learning 
has been transformative, to some extent expanded learning (Engesrtrøm 1990). The researchers have tried to become insiders, helping practitioners reflect over own practice. The Fagskolen (Fach-hochshole) was intended to run what became the bachelor course. When even this part of the course was given by the university, we combined academic and vocational education. In the process, also the university lecturers have learned. Thus there is a case for calling this symbiotic learning.

\section{Acknowledgement}

An earlier version of this paper was presented at: Conference on Learning Outside the Formal Educational System and in alternating between formal, informal and nonformal learning, June 1 - 3, 2015, Oslo and Akershus University College of Applied Sciences. I should like to thank Professors Richard Ennals and Olav Eikeland for valuable comments. 


\section{References}

Docherty P., Kira M., \& Shani A. R. (Eds.). (2008). Creating sustainable work systems: developing social sustainability. Routledge.

Engerström Y. (1990). Learning, Working and Imagining. Twelve Studies in Activity Theory, Orientakonsultit, Helsinki.

Eikeland O. (2013). “Symbiotic Learning Systems: Reorganizing and Integrating Learning Efforts and Responsibilities Between Higher Educational Institutions (HEIs) and Work Places”. Journal of the Knowledge Economy, 4(1), 98-118.

Elkington J. (2012). The zeronauts: breaking the sustainability barrier. London: Routledge.

Ennals R., Göranzon B., Nelson B. \& Alvunger D. (2016) "Dialogue, Skill and Tacit Knowledge: Practical Knowledge and Corporate Social Responsibility”. In eds. Habisch A. and Schmidpeter R. Cultural Roots of Sustainable Management: Practical Wisdom and Corporate Social Responsibility. Switzerland, Springer International.

Gustavsen B. 1992: Dialogue and development: theory of communication, action research and the restructuring of working life. Assen/Maastricht: Van Gorcum.

Heck S., \& Rogers M. Resource Revolution: How to Capture the Biggest Business Opportunity in a Century. Houghton Mifflin Harcourt, 2014, pages xi -18 and 69-98

Johnsen H.C.G. 2001: Involvement at work. København: Samfundslitteratur.

Johnsen H.C.G, Torjesen S. \& Ennals R. (eds.) (2015). Higher Education in a Sustainable Society. Heidelberg, Springer.

Landmark K., Rodvelt M., \& Torjesen S. (2015). "Agder as Mutual Competence Builders: Developing Sustainability as a Competitive Advantage". In Higher Education in a Sustainable Society (pp. 197-205). Heidelberg, Springer.

Levin, M., Nilssen, T., Ravn, J. E., \& Øyum, L. (2012). Demokrati i arbeidslivet. Den norske samarbeidsmodellen som konkurransefortrinn. Fagbokforlaget Vigmostad and Bjørke AS, Bergen.

Pålshaugen Ø. 2002. "Discourse democracy at work: On public spheres in private enterprises”. In: Concepts and Transformation 7:1, 2002.

Porter, M.E., \& Kramer M.R. 'Creating shared value' Harvard Business Review 89, no. 1/2 (2011): 62-77.

Toulmin S. \& Gustavsen B. (eds.). 1996: Beyond theory: Changing organizations through communication. Amsterdam: John Benjamins.

Vision 2050 - the New Agenda for Business - in brief (English summary) WBCSD, 2010, pages 1-19 http://www.wbcsd.org/pages/edocument/edocumentdetails.aspx?id=219

Wig B.B. 2013: Lean : ledelse for læerende organisasjoner. Oslo : Gyldendal arbeidsliv.

Winston A. "Resilience in a hotter world." Harvard Business Review 92, no. 4 (2014): 56-64. http://hbr.org/2014/04/resilience-in-a-hotter-world/ar/1

Kotter, J. P. (1996). Leading change. Harvard Business Press.

\section{About the author:}

Hans Christian Garmann Johnsen

Professor at the department of Working Life and Innovation, University of Agder

hans.c.g.johnsen@uia.no 